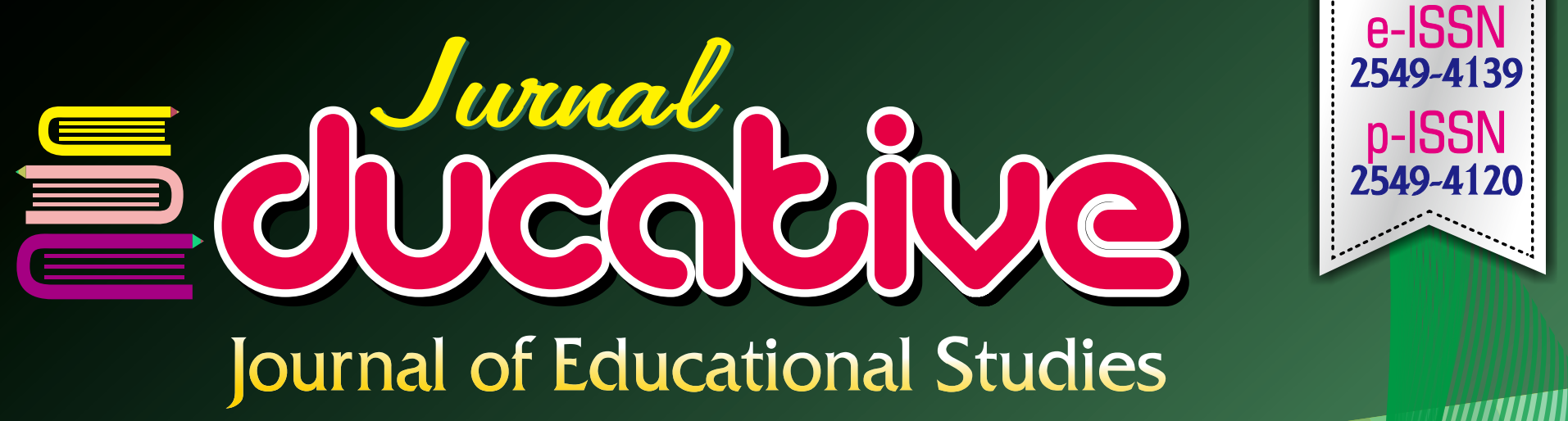

\title{
Journal of Educational Studies
}

جهود العلماء الإندونيسيين فى ترجمة ألفاظ القر آن الكريم

(الدر اسة التحليلية لترجمة معانى الألفاظ العلمية الكونية القر آنية فى إندونيسيا، قضايا وحلول) Arman Husni

Efektivitas Layanan Bimbingan Kelompok Terhadap

Kualitas Interaksi Sosial Anak Asuh

Ardimen, Devi Yani Natalia, Rafsel Tas'adi, Rosa Dovita

Efektifitas Teknik Tandur (Tumbuhkan, Alami, Namai, Demonstrasi, Ulangi dan Rayakan) Pada Mata Pelajaran IImu Pengetahuan Alam $p$ ada Kelas V SD Negeri 37 OkU

Ade Vidianti

Conscientiousness and Emotional Stability on Students'

Speaking Ability through Flipped Classroom

Reflianto, Farida Ariani

Expert Appraisal on Islamic Textual Enhancement Grammar Book Designed for Grammar Teaching at IAIN Bukittinggi

Veni Roza, Genta Sakti

Kemampuan Mahasiswa Camper dalam Merekonstruksi Irisan Prisma M. Imamuddin, Isnaniah

Teaching Reading by Using Paragraph Shrinking Strategy Ridianto

Komparasi Hasil Prestasi Belajar Siswa Sekolah Dasar Inklusi dan Homeschooling

Sukarman, Azzah Nor Laila, Alex Yusron Al Mufti 


\title{
KOMPARASI HASIL PRESTASI BELAJAR SISWA SEKOLAH DASAR INKLUSI DAN HOMESCHOOLING
}

\author{
Sukarman \\ Fakultas Tarbiyah dan Ilmu Keguruan - UNISNU \\ E-mail:pakar@unisnu.ac.id \\ Azzah Nor Laila \\ Fakultas Tarbiyah dan Ilmu Keguruan - UNISNU \\ E-mail:azzab@unisnu.ac.id \\ Alex Yusron Al Mufti \\ Fakultas Tarbiyah dan Ilmu Keguruan - UNISNU \\ E-mail:goesxela@gmail.com \\ Diterima : 06 Juli $2018 \quad$ Direvisi : 28 November 2018 \\ Diterbitkan : 30 Desember 2018

\begin{abstract}
This study aims to describe the comparation of student achievement results of Primary School Semai Jepara with Homeschooling Primagama Semarang. Because both institutions have similarities in the category of inclusive schools, which accept all children as students based on quotas. In this study, the learning achievement studied is only the value of the main subjects namely Indonesian, Mathematics, and Natural Sciences. The result of research shows that Indonesian and Mathematics score from Semai Primary School students is superior to Homeschooling Primagama Semarang. However, in the subjects of Natural Sciences, students of Homeschooling Primagama Semarang are superior. In general, the average value of learning achievement of the main subjects obtained the conclusion of SD Semai Jepara is superior to Homeschooling Primagama Semarang.
\end{abstract} \\ Keywords: achievement, primary school, Homeschooling.
}

\section{Abstrak}

Penelitian ini bertujuan untuk mendeskripsikan komparasi hasil prestasi siswa Sekolah Dasar Semai Jepara dengan Homeschooling Primagama Semarang.Karena kedua lembaga tersebut memiliki kesamaan dalam hal kategori sekolah inklusi, yang menerima semua anak sebagai siswa berdasarkan kuota.Dalam penelitian ini, prestasi belajar yang diteliti hanya nilai dari mata pelajaran utama yaitu Bahasa Indonesia, Matematika, dan Ilmu Pengetahuan Alam. Hasil penelitian menunjukkan nilai Bahasa Indonesia rata-rata 91,3 dan Matematika 82 dari siswa Sekolah Dasar Semai lebih unggul dibandingkan Homeschooling Primagama Semarang. Namun pada mata pelajaran Ilmu Pengetahuan Alam, nilai siswa Homeschooling Primagama Semarang lebih unggul dengan rata-rata 83,31. Secara umum nilai rata-rata prestasi belajar mata pelajaran utama diperoleh kesimpulan SD Semai Jepara lebih unggul dibandingkan Homeschooling Primagama Semarang.

Kata kunci: prestasi, Sekolah Dasar, Homeschooling.

\section{Latar Belakang}

Sekolah inklusi menjadi penting karena mengusung kesetaraan, dimana setiap orang memiliki hak sama untuk mendapatkan pendidikan. Hal ini sesuai dengan Undang Undang Dasar 1945 pasal 31 ayat 1 dan 2, bahwa setiap warga negara mempunyai kesempatan sama memperoleh pendidikan. Tanpa membedakan satu anak dengan lainnya. 
Selain itu, Undang-Undang nomor 20 tahun 2003 tentang sistem pendidikan nasional pasal 3, 5, 32, Undang-Undang nomor 23 tahun 2001 tentang perlindungan anak pasal 48 dan 49. Dimana pada intinya menjelaskan kesempatan mendapatkan pendidikan untuk anak harus diberikan seluas-luasnya baik oleh orangtua, keluarga, pemerintah, dan Negara.

Sekolah inklusi merupakan sekolah regular biasa yang menerima semua anak baik anak tanpa kebutuhan khusus (ATBK) dan anak berkebutuhan khusus (ABK).Sekolah menyediakan layanan sesuai kebutuhan anak.Prinsip dasar dari sekolah inklusi adalah selama memungkinkan semua anak seyogyanya belajar bersama tanpa memandang kesulitan atau perbedaan yang ada pada mereka.Setiap anak atau peserta didik diterima menjadi bagian dari siswa di sekolah selama sesuai kuota, sehingga kebutuhan individual maupun sosialnya terpenuhi.

Hal itu karena hakikat pendidikan mengandung aspek pengembangan potensi anak baik secara individual maupun sosial. Sebagaimana menurut Sugiyono,bahwa pendidikan adalah usaha sadar dan terencana untuk mewujudkan proses pembelajaran, agar peserta didik dapat mengembangkan potensinya untuk memiliki kekuatan spiritual, pengendalian diri, kepribadian, kecerdasan, akhlak mulia, serta ketrampilan yang diperlukan. Baik untuk pribadi, masyarakat, bangsa serta negara. ${ }^{1}$

Sedangkan menurut Mulyasa,pendidikan adalah usaha sadar untuk mencapai tujuan makro serta mikro. Tujuan secara makroyaitu mencetak generasi yang bernalar, mampu berkomunikasi sosial dengan cara positif, sehat, memiliki sumber daya manusia tinggi, dan tangguh. Dan secara mikro bertujuan membentuk manusia beriman, bertakwa pada

1 Sugiyono, Metode Penelitian Pendidikan : Pendekatan Kuantitatif, Kualitatif, dan R \& D, (Bandung: Alfabeta, 2010), h. 42
Tuhan Yang Maha Esa, beretika, dan berwawasan budaya bangsa Indonesia. ${ }^{2}$

Untuk merealisasikan tujuan luhur tersebut, pemerintah Indonesia membagi jalur pendidikan menjadi tiga macam.Pertama, pendidikan formal yang merupakan pendidikan terstruktur dan berjenjang dari tingkat dasar, menengah, dan pendidikan tinggi. Selain itu juga diatur secara sistematis, syarat dan regulasinya secara legal formal dalam aturan pemerintah. ${ }^{3} . K e d u a$, pendidikan non formal sebagai jalur pendidikan di luar formal yang bisa dilaksanakan secara terstruktur dan berjenjang. Ketiga, pendidikan informal yang merupakan jalur pendidikan lingkungan dan keluarga. ${ }^{4}$

Lembaga pendidikan baik formal maupun non formal dapat membuka program inklusi.Diantaranya ada beberapa Sekolah formal yang termasuk sekolah inklusi, baik tingkat Sekolah Dasar (SD), Sekolah Menengah Pertama (SMP), dan Sekolah Menengah Atas (SMA). Sedangkan lembaga non formal yang menyediakan program inklusi antara lainHomeschooling.Dan keduanya tentu tidak lepas dari kelebihan dan kekurangan masing-masing.

Kelebihan sekolah formal diantaranya dari sistem regulasinya, yang berjenjang secara terstruktur dengan kurikulum serta aturan pasti dari pemerintah.Secara finansial operasional sekolah formal lebih ringan karena mendapat subsidi pemerintah.Sedangkan kelebihan bomeschooling, anak lebih memiliki kebebasan memilih kurikulum.Sehingga memberikan peluang anak dalam mencapai kompetensi individual semaksimal mungkin,

2 Mulyasa, E., Kurikulum Berbasis Kompetensi, Bandung: Remaja Rosdakarya, 2010), h. 21

3 Maunah, Perbandingan Pendidikan Islam, (Yogyakarta: Teras,2011), h. 119

4UU RI No. 20 Tahun 2003 tentang Sisdiknas, 2014, Bandung: Citra Umbara. 
tanpa dibatasi perbandingan kemampuan tertinggi, rata-rata atau terendah. ${ }^{5}$

Proses belajar dapat dilakukan dimana saja baik di rumah, kebun, dan tempat lain yang memungkinkan anak mendapatkan pengetahuan. $^{6}$

Adapun kelemahan homeschooling sebagai model pendidikan antara lain; anak kurang bersosialisasi dengan teman sebaya serta cenderung individual. Kurangnya pengalaman berorganisasi karena tidak terlibat dalam kegiatan sosial, seperti OSIS, PMR, Pramuka, dan lainnya. Dan tingginya biaya homeschooling, karena tidak ada dana subsidi dari pemerintah. ${ }^{7}$

Sedangkan kelemahan sekolah formal diantaranya kurikulum selalu berubah sehingga berdampak pada perubahan buku dan beban mata pelajaran. ${ }^{8}$ Pergaulan komunitas anak yang heterogen memberi dampak buruk pada perilaku anak. Diantaranya kekerasan antar teman, bullying, terlibatnya pergaulan bebas, dan adanya pelajar yang terjerat narkoba.

Meskipun Sekolah Inklusi Formal dan Homeschooling memiliki kekurangan serta kelebihan masing-masing, bahkan berbeda jalur antara formal dan non formal. Namun keduanya juga memiliki kesaamaan antara lain; keduanya memiliki kesamaan mengusung kesetaraan dan menerima semua anak sebagai siswa selama kuota masih ada, menggunakan

5 Moreau, Kathi, Specific Differences In The Educational Outcomes Of Those Students Who AreHome Schooled VS. Students In A Traditional School Setting, (Northern: Michigan University, 2012), h. 3

${ }^{6}$ Griffith, Mary, Sekolah di rumah, Memanfaatkan Seluruh Dunia Sebagai Ruang Kelas, The Unschooling Handbook, (Bandung: Nuansa, 2008), h. 45

7 Asmani, Jamal Ma'mur, Buku Pintar Home Schooling, (Jogjakarta: FlashBooks, 2012), h. 117-123

8 Mulyadi, Seto, Homeschooling Keluarga Kak-Seto: Mudah, Murah, Meriah, dan Direstui Pemerintah, (Bandung: Kaifa PT Mizan Pustaka, 2007), h. 136

9 Wijayarto, Budi, dan Haryanto, Perbandingan Kompetensi Sosial Siswa Komunitas Homeschooling dengan siswa regular SD Muhammadiyah 1 Surakarta, (Jurnal Prima Edukasia, Volume 3 - Nomor 1, 2015), h. 63 kurikulum Nasional, dan mengikutsertakan siswa kelas akhir dalam Ujian Akhir Sekolah Berstandar Nasional (UASBN) sesuai regulasi Pemerintah.

Hal itulah yang menjadi alasan peneliti melakukan penelitian dengan membandingkan hasil prestasi siswa sekolah formal inklusi dengan homeschooling.Dalam hal ini peneliti fokus pada pendidikan anak tingkat dasar, sekolah dasar dan homeschooling yang setara dengan jenjang tersebut.Bagaimana perbedaanoutputanak yang belajar di pendidikan formal tingkat Sekolah Dasar danprogram homeschooling?. Penelitian ini dibatasi pada dua tempat, yaitu salah satu sekolah dasar yang termasuk sekolah inklusi adalah Sekolah Dasar Semai Jepara dan Homeschooling Primagama Semarang.Sedangkan hasil prestasi yang dikomparasikan adalah hasil prestasi mata pelajaran utama Ujian Akhir Sekolah Berstandar Nasional (UASBN), yaitu Bahasa Indonesia, Matematika, dan Ilmu Pengetahuan Alam.

\section{Hasil dan Pembahasan}

\section{Pendidikan Inklusi}

Pendidikan secara etimologi berasal dari bahasa Latin educare, yang artinya memasukkan sesuatu.Dalam bahasa Arab berasal dari kata rabba, yang merupakan akar kata dari tarbiyahdan memiliki arti memelihara, menambah, mengembangkan. ${ }^{10}$ Maka secara istilah pendidikan merupakan proses perubahan sikap atau perilaku seseorang maupun kelompok dalam rangka berusaha mendewasakan manusia melalui pengajaran, proses, dan aktfitas mendidik. ${ }^{11}$

10 Mandhur, Ibnu, t.t., Lisanul 'Arab, (Riyadl: Dar al-Ma'arif, 1990), h. 386

11 Darmadji, 2013, Tafsir al-Qur'an Tentang Teori Pendidikan Islam: Perspektif Pendidikan Islam di Indonesia, Hermeneutik Jurnal Tafsir Hadits, volume 9, No.1, Januari-Juni, 223-244. 
Sedangkan pendidikan inklusi merupakan penyelenggaraan pendidikan dengan mengakomodasi semua anak tanpa membedakan kondisi fisik, intelektual, emosional, atau kondisi lainnya. Semua anak diperlakukan sama, baik anak normal pada umumnya (regular) maupun anak berkebutuhan khusus (ABK). Pelayanan pendidikan diberikan secara bersamaan, sehingga terjadi interaksi antara mereka. ${ }^{12}$

Dalam interaksi keseharian mereka harus saling memahami, menghargai perbedaan, dan bagi anak-anak regular menjadi media untuk meningkatkan empati mereka.

Secara yuridis, dasar dilaksanakannya pendidikan inklusi adalah Undang Undang Pasal 31 yang menyebutkan bahwa semua warga negara memiliki hak untuk mendapatkan pendidikan. Kemudian dijabarkan pada Undang-Undang Nomor 20 Tahun 2003 pasal 5 tentang sistem pendidikan nasional dan Permendiknas No. 70 Tahun 2009 Tentang Pendidikan Inklusi. ${ }^{13}$

Model pembelajaran anak berkebutuhan khusus di sekolah inklusi dapat digolongkan menjadi enam model.Pertama, model kelas regular atau inklusi penuh.Artinya anak berkebutuhan khusus yang tidak mengalami gangguan intelektual mengikuti pembelajaran di kelas bersama anak regular lainnya.Kedua, model cluster.Model ini merupakan model pengelompokan, yang mana anak berkebutuhan khusus dikelompokkan dengan pendamping khusus tetapi tetap dalam satu kelas dengan anak regular.Ketiga, model pull outyaitu pada saat tertentu anak berkebutuhan

12 Direktorat PSLB, Pedoman Penyelenggaraan Pendidikan Inklusi (Buku Paket), Jakarta: Direktorat PSLB, 2004.

13 Pratiwi, Jamilah Candra, "Sekolah Inklusi Untuk Anak Berkebutuhan Khusus: Tanggapan Terhadap Tantangan Kedepannya", Prosiding Seminar Nasional Pendidikan; Meretas Sukses Publikasi Ilmiah Bidang Pendidikan Jurnal Bereputasi", Universitas Sebelas Maret Surakarta, ISBN: 978-979-3456-52-2, 237-242, 2015 khusus (ABK) ditempatkan di luar kelas reguler seperti ruang khusus dengan pendamping tersendiri. Keempat, model cluster and pull out, yakni model kombinasi antara model cluster dan pull out. Kelima, model kelas khusus, sekolah menyiapkan satu kelas khusus untuk anak berkebutuhan khusus (ABK), tetapi saat kegiatan pembelajaran tertentu digabung dengan anak reguler lainnya.Keenam, model khusus penuh, pada model ini anak berkebutuhan khusus (ABK) ditempatkan pada satu kelas tersendiri dengan pembelajaran di bawah guru pendamping khusus.Dan lokasi kelas masih satu atap dengan kelas anak reguler lainnya.

Dalam pendidikan inklusi perlu adanya proses assesmen dengan beberapa langkah untuk memperoleh hasil pelaksanaan pendidikan. Diantara langkahnya adalah; 1). Screening, proses mencari indicator kemampuan dengan berbagai cara baik melalui orangtua, siswa, guru atau menilai secara langsung dengan beberapa tes. 2). Identifikasi, mendalami dan mengidentifikasi kecocokan program pendidikan dengan kemampuan anak. 3). Perencanaan program terkait dengan kesesuaian materi pembelajaran dengan kebutuhan anak. 4). Evaluasi, mengukur program yang sudah dilaksanakan dengan hasil belajar anak. ${ }^{14}$

Pada realitanya pendidikan inklusi jumlahnya lebih sedikit bila dibandingkan sekolah reguler biasa. Meskipun hakikatnya sekolah inklusi menjadi bagian dari pemenuhan kesamaan hak anak-anak. Tanpa membedakan anak normal dengan anak berkebutuhan khusus (ABK). Akan tetapi pendidikan inklusi belum sepenuhnya diterima serta diaplikasikan secara menyeluruh. Hal itu diantaranya karena pengaruh persepsi orangtua siswa. Sebagaimana hasil salah satu penelitian

14 Suharni, "Pemahaman Guru Dalam Layanan Bimbingan Pada Sekolah Penyelenggara Pendidikan Inklusi", Jurnal Care Edisi Khusus Temu Ilmiah, Volume03, Nomor3, Maret 1, 2016 
di provinsi Lampung, 74 persen orangtua menyetujui pendidikan inklusi di tingkat sekolah dasar. Dan 36 persen orangtua tidak setuju, karena mereka khawatir akan munculnya dampak negatif. ${ }^{15}$

\section{Homeschooling}

Homeschooling berasal dari kata home yang berarti rumah dan schooling yang berarti sekolah. Homeschooling sering disebut dengan istilah bome-education atau bome-based learning ${ }^{16}$ Homeschooling diadakan dengan harapan anak-anak tidak hanya memperoleh nilai akademik saja, tetapi juga memiliki ketrampilan serta soft skill untuk bekal di masa depan mereka dan kemajuan bangsa.

Homeschooling didirikan atas dasar tiga faktor.Pertama, untuk membantu anak-anak yang secara psikologis dianggap bermasalah.Seperti anak yang tidak suka sistem formal atau berkebutuhan khusus.Kedua, anak yang tidak dapat mengakses pendidikan formal karena letak geografis rumah.Ketiga, faktor ekonomi dengan alasan tidak mampu menanggung biaya pendidikan.

Homeschooling hakikatnya berlandaskan pada teori pendidikanhumanistik.Pendidikan yang memiliki ciri lebih menekankanproses pengembangan kemampuan siswa secara manusiawi. Sehingga materi dan proses pembelajaran dapat berubah sesuai minat serta kebutuhan siswa. Kurikulum bersifat fleksibel dan tidak baku.

Secara yuridis Homeschooling berada di bawah regulasi sebagi payung hukumya antara lain:

A. UUD 1945 Negara Kesatuan Republik Indonesia Pasal 31 ayat (1) setiap warga behak atas pendidikan. Ayat (2) setiap

15 Tri Yuni Hendrowati, Persepsi Orang Tua Terhadap Pendidikan Inklusif Sekolah Dasar Di Provinsi Lampung, Jurnal Fokus Konseling, Volume 3, No.1, Januari 2017, h. 82-83.

16 Kembara, Maulina D. (2007). Panduan Lengkap Home Schooling, (Bandung: Progressio, 2007), h. 28 . warga negara wajib mengikuti pendidikan dasar dan pemerintah wajib membiayainya.

B. Undang-undang Sistem Pendidikan Nasional UU No. 20/2003 tentang Sistem Pendidikan Nasional.

Pasal 13 ayat (1) Jalur pendidikan terdiri atas formal, nonformal dan informal yang dapat saling melengkapi dan memperkaya.

Pasal 26 ayat (1) Pendidikan nonformal diselenggarakan bagi warga masyarakat yang memerlukan layanan pendidikan yang berfungsi sebagai pengganti, penambah, dan/atau pelengkap pendidikan formal dalam rangka mendukung pendidikan sepanjang hayat. Ayat (4) Satuan pendidikan nonformal terdiri dari lembaga kursus, lembaga pelatihan, pusat kegiatan belajar masyarakat, dan majlis taklim serta satuan pendidikan yang sejenis. Ayat(6) Hasil pendidikan nonformal dapat dihargai setara dengan hasil pendidikan formal setelah melalui proses penilaian penyetaraaan oleh lembaga yang ditunjuk oleh Pemerintah Daerah dengan mengacu pada Standar Pendidikan Nasional dalam halnini pemerintah tidak mengatur standar isi dan proses pelayanan informal kecuali standar penelitian apabila disetarakan dengan pendidikan jalur formal dan nonformal sebagaimana dinyatakan dalam UU No. 20/2003.

C. Surat Edaran Menteri Pendidikan Nasional Republik inbdonesia No. 107/MPN/MS/2006.

1. Setiap orang yang lulus ujian kesetaraan paket $\mathrm{A}$, paket $\mathrm{B}$, atu paket $\mathrm{C}$ masing-masing memiliki hak yang sama dan setar dengan, berturut-turut, pemegang ijasah SD/MI/SMP/Mts, dan SMA/MA/SMK untuk dapat mendaftar pada satuan pendidikan yang lebih tinggi.

2. Status kelulusan program pendidikan kesetarn paket $\mathrm{C}$ memiliki hak eligilitas 
yang setar dengan pendidikan formal dalam memasuki lapangan kerja.

3. Setiap lembaga diminta mematuhi ketentuan perundang-undangan tersebut di atas agar tidak diiindikasikan melanggar hak asasi manusia.

D. Peraturan Menteri Pendidikan Nasional No. 129 Tahun 2014 tentang "Sekolah Rumah" yaitu.

1. Pasal 1 ayat (4) Sekolah rumah adalah proses layanan pendidikanyang secara sadar dan terencana dilakukan oleh orangtua/keluarga di rumah atau tempat-tempat lain dalam bentuk tunggal, majemuk, dan komunitas dimana proses pembelajaran dapat berlangsung dalam suasana yang kondusif dengan tujuan agar setiap potensi didik dapat berkembang maksimal.

2. Pasal 4 ayat (1) hasil pendidikan sekolah rumah diakui sama dengan pendidikan formal dan nonformal setelah peserta didik lulus ujian sesuai atandar nasional pendidikan.

3. Pasal 12 peserta didik sekolah rumah dapat mengikutu UN/UNPK pada satuan pendidikan formal atau nonformal yang disetujui atau ditunjuk Dinas Pendidikan Kabupaten/Kota setempat.

Hal penting dalam Homeschooling adalah mayoritas aktivitas pembelajaran dilakukan di rumah menggunakan kurikulum terstruktur.Selain itu, tanggungjawab pelaksanaan pendidikan ada pada orangtua serta anak.Dan inti dari pembelajaran homeschooling adalah belajar dapat dilakukan di mana pun, oleh atau dengan siapa pun, serta kapan pun. ${ }^{17}$

${ }^{17}$ Marsha Ransom, The Complete Idiot's Guide to Homeschooling, (USA: Alpha Publishing, 2001).
Homeschooling secara umum dibagi menjadi tiga macam.Sebagaimana dalam Permendiknas Nomor 129 Tahun 2014, pasal 1 ayat 4.Pertama, homeschooling tunggal. Suatu proses pendidikan yang pelaku utamanya adalah keluarga dan rumah sebagai tempat belajar. Kedua, homeschooling majemuk.Pada model ini pelakunya tidak hanya satu keluarga inti.Akan tetapi dilakukan beberapa keluarga.Ketiga, homeschooling komunitas.Suatu kelompok membentuk komunitas belajar secara klasikal dengan materi dan metode tertentu. ${ }^{18}$ Bila dilihat dari namanya, jenis kedua dan ketiga tampak sama karena dilakukan secara berkelompok tidak individual. Dimana beberapa anak sebaya dikelompokkan dalam kelas kapasitas kecil.Pada prakteknya memiliki kesamaan pula dengan pembelajaran di sekolah formal.

Ketiga model homeschooling tersebut memiliki kekurangan dan kelebihan masingmasing.Kelebihan homeschooling tunggal adalah semangat belajar anak lebih tinggi karena waktupembelajaran dapat diatur sesuai kenyamanan anak, kedekatan anak dengan keluarga semakin terbentuk dengan baik. Adapun kekurangannya antara lain belum ada legalitas, pengetahuan orangtua sebagai tutor masih terbatas, serta kurang update dalam hal informasi perkembangan peraturan pendidikan dari pemerintah. ${ }^{19}$

Adapun kelebihan homeschooling majemuk dan komunitas antara lain kompetensi sosial anak homeschooling lebih tinggi daripada siswa SD regular, karena beberapa inovasi program homeschoolingdengan kegiatan penunjang seperti:

${ }^{18}$ Direktorat Pendidikan Kesetaraan, Komunitas Sekolah Rumah Sebagai Satuan Pendidikan Kesetaraan, (Jakarta: Dirjen Pendidikan Luar Sekolah, 2006).

${ }^{19}$ Vania Widyadana Zahida dan Winarsih Dewi, Homeschooling Tunggal Sebagai Model Pendidikan Pilihan Bagi Anak (Studi Analisis Penerapan Konsep Homeschooling Pada Princess), Prosiding Seminar Nasional: Homeschooling Versus Sekolah Formal Dialog Tentang Mutu Pendidikan Yang Bermartabat, Oktober, 2016, h. 30-31. 
project class, student of the month, inspiring story, games.Hal itudapat memperbanyak proses interaksi dan sosialisasi anak homeschooling. Kemudian adanya layanan Psikolog yang melayani kebutuhan konsultasi anak maupun orangtua. ${ }^{20}$ Sehingga kebutuhan psikologis anak terpenuhi seperti perhatian, kasih sayang, perasaan dihargai, serta hubungan keharmonisan dalam keluarga dan sosial dapat terkontrol.

Sedangkan kekurangannya antara lain; menurut Siagian \& Nurfitriyanti minat belajar anak homeschoolingtergolong rendah,karakter anak bomeschooling tidak terlalu tinggi karena porsi pembinaan karakter anak dalam kurikulum homeschooling kurang optimal, dan motivasi orang tua dalam mendorong anaknya belajar kurang stabil. ${ }^{21} \mathrm{Hal}$ itu menunjukkan bahwa motivasi atau semangat itu fluktuatif.Adakalanya meningkat, sehingga orangtua semangat mendampingi serta mendorong anaknya belajar. Sebaliknya, saat menurun maka tidak akan muncul semangat tersebut.

\section{Profil Sekolah Dasar Semai Jepara}

Sekolah Dasar Semai merupakan salah satu sekolah dasar swasta di Jepara. Sekolah dasar ini didirikan berdasarkan filosofi bahwa anak adalah individu yang unik, setiap anak memiliki kebutuhan, minat, tahap perkembangan serta gaya belajar yang berbeda. Sekolah Dasar Semai mengakomodir keunikan individu setiap anak dalam prespektif hak anak dan kecerdasan majemuk (Multiple Intellegences) sebagai pertimbangan utama.Sehingga sekolah

20 Wijayarto, Budi, dan Haryanto, Perbandingan Kompetensi Sosial Siswa Komunitas Homeschooling dengan siswa regular SD Muhammadiyah 1 Surakarta, Jurnal Prima Edukasia, Volume 3 - Nomor 1, 2015

21 Siagian, Roida Eva Flora, dan Maya Nurfitriyanti, Minat Belajar dan Karakter Anak Dalam Model Pendidikan Homeschooling di JABODETABEK, Jurnal Pendidikan Karakter, Tahun IV, Nomor 3, Oktober, 2014 dasar Semai menerima semua siswa sesuai kuota serta mendaftar pada waktu yang ditentukan, tanpa membedakan kondisi psikologis anak.Baik anak dengan kondisi normal, maupun anak berkebutuhan khusus tetap diterima di Sekolah Dasar Semai.Hal itulah yang menjadikan Sekolah Dasar Semai ini termasuk sekolah dasar inklusi.

Misi dari Sekolah Dasar Semai adalah 1). Membiasakan pola hidup sehat melalui olah raga, pendidikan kesehatan serta pengelolaan lingkungan yang berbasis 3R (Reduce, reuses, recycle). 2). Menyelenggarakan pembelajaran partisipatif yang mengutamakan pada proses pengembangan kecerdasan majemuk anak untuk mengoptimalkan kreatifitas dan kemandirian. 3). Menumbuhkembangkan nilai religius, jiwa nasionalism, kepekaan social dan apresiasi seni budaya pada anak melalui berbagai kegiatan intra dan ekstra sekolah.

Kurikulum Sekolah Dasar Semai merujuk pada filosofi yang telah dirumuskan pada visi dan misi, kurikulum dan seluruh program pebelajaran SD Semai menggunakan alur sebagai berikut:

\section{Input}

Kegiatan Penerimaan Peserta Didik Baru (PPDB) SD Semai seluruh anak diterima baik Anak Tanpa Kebutuhan Khusus (ATBK) dan Anak Berkebutuhan Khusus (ABK) namun disesuaikan dengan kuota atau daya tampung sekolah.

Dalam rangka pemenuhan input SD Semai melakukakan beberapa tahapan yaitu: (a). Pembentukan Panitia Penerimaan Siswa Baru (PSB) atau Panitia Penerimaan Peserta Didik Baru (PPDB). Pembentukan Panitia Penerimaan Peserta Didik Baru (PPDB) melakukan penerimaan peserta didik baru terdiri dari unsur guru dan dan karyawan. (b). Sosialisasi kepada masyarakat. Selanjutnya setelah pembentukan panitia PPDB adalah melakukan sosialisasi kepada masyarakat 
melalui media cetak dan elektronik; (c). Pendaftaran siswa / peserta didik baru. Tahap berikutnya adalah pendaftaran siswa / peserta didik baru yang meliputi observasi anak dan wawancara orang tua.Dalam tahap ini panitia PPDB mendata identitas dan mendokumentasikan calon siswa yang mendaftar.Setelah itu panitia PPDB melakukan observasi dan wawancara dengan orang tua.Kegiatan ini dilakukan guna memperoleh spesifikasi siswa dengan membuat kategori Anak Tanpa Kebutuhan Khusus (ATBK) dan Anak Berkebutuhan Khusus (ABK) berdasarkan hasil observasi dan wawancara dengan orangtua; (c) Multiple Intelligence Research (MIR). MIR adalah penelitian kecerdasan ganda yang dilakukan untuk pemetaan kecerdasan, bakat, dan peminatan siswa agar dapat dibina dan dikembangkan kedepannya; (d). Stadium general; Stadium general merupakan forum yang didikuti oleh semua peserta didik baru atau forum berkumpulnya semua peserta didik baru yang secara resmi diterima di SD Semai. (e). Pengenalan Lingkungan Sekolah (PLS). Kegiatan ini merupakan agenda akhir yang diselenggarakan oleh panitia PPDB.Kegiatan PLS ini merupakan kegiatan orientasi yang diselenggarakan agar siswa mengenali lingkungan tempat belajarnya baik unsur guru karyawan (personal), bangunan, fasilitas (material) dan sebagainya.

Proses.

Seluruh proses pembelajaran, menggunakan pendekatan kecerdasan jamak, yang terdapat dalam kegiatan belajar di dalam kelas maupun di luar kelas.

Kecerdasan Jamak, menjadi strategi belajar yang kaya dan membahagiakan. Strategi belajar yang diterapkan di SD Semai menggunakan lebih dari 95 strategi belajar berbasis kecerdasan jamak antara lain sebagai berikut: (a). Applied Learning; (b). Service learning; (c). Sosiodrama; (d). Game; (e). Film; (f). Parodi; (g). Presentasi; (h). Penelitian; (i). Wawncara; (j). Eksperimen; (k). Demonstrasi; (l). Diskusi; (m). Klasifikasi; (n).Identifikasi.

\section{Output}

Luaran (Output) SD Semai dilihat melalui tiga ranah kompetensi yakni kognitif, psikomotorik dan afektif.

Kegiatan lain yang diberikan oleh SD Semai sebagai penunjang kurikulum dan pengembangan bakat anak dilakukan dengan membuat beberapa club antara lain:

\section{Club rebana}

Club rebana merupakan wadah yang bertujuan untuk mengembangkan bakat/kreatifitas seni anak. Kegiatan ini juga mengembangkan sikap religius anak karana club rebana membawakan lagu-lagu yang bernafaskan Islam berupa lagu dengan lirik pesan-pesan islami dan sholawat kepada Nabi Muhammad saw. Selain itu club rebana ini juga dapat digunakan sebagai media sosialisasi program pendidikan SD Semai ketika tampil mengisis acara baik acara sekolah seperti upacara kenaikan kelas ataupun wisuda. Selain itu dapat juga ditampilkan pada acara di luar sekolah misalnya undangan masyarakat seperti tampil pada acara pengajian, khitanan, walimah tasmiyah ataupun pernikahan.

\section{Club visual.}

Club visual merupakan bentuk kegiatan berupa kelompok belajar yang menggunakan media yang 'dapat ditangkap dengan indera penglihatan. Mediavisual tersebut dapat berupa gambar maupun video pembelajaran. Hal ini dilatarbelakangi karena anak-anak menyukai hal-hal visual seperti tokoh kartun atau yang lainnya sehingga hal ini bisa dgunakan untuk kegiatan pembelajaran. 


\section{Club English}

Club English merupakan sebuah wadah yang bertujuanuntuk mengembangkan kemampuan berbahasa anak terutama bahasa Inggris. Hal ini dilatarbelakangi bahwa bahasa Inggris merupakan Bahasa internasional. Terlebih jepara merupakan kota dengan penghuni warna negara asing (WNI) yang cukup besar karena Jepara merupakan kota yang menjadi sentra kesenian ukir dan meubel yang menjadi tujuan bagi para pelaku bisnis dari mancanegara. Selain itu Jepara juga merupakan destinasi wisata seperti Pantai Kartini dan Pulau Karimun Jawa.

Kegiatan club English tersebut membuahkan hasil dengan menjuarai beberapa lomba pidato.

\section{Club handy craft}

Club handicraft merupakan sebuah wadah yang bertujuan mengembangkan kreatifitas siswa dalam bidang kerajinan tangan. SD Semai mnerapkan program pengolahan limbah untuk didaur ulang sehingga memiliki nilai lebih dan tidak berakhir menjadi sampah. Program tersebut 3R. Pertama, reduce (mengurangi penggunaaan sampah).Siswa SD semai dijari sejak dini untuk mengurangi penggunaan sampah dengan membawa bekal makanan dari rumah sehingga dapat mengurangi kebiasaan jajan anak yang umumnya menimbulkan sampah dari bungkus kemasannya. Kedua, reuse (memanfaatkan kembali sampah). Siswa SD Semai diajari untuk menggunakan kembali limbah misalnya kaleng untuk dimanfaatkankembali menjadi wadah pensil, pot bunga atau yang lainnya. Ketiga, recycle (mendaur ulang limbah). Siswa SD Semai diajari bagaimana mendaur ulang limbah menjadi barang-barang yang mempunyai nilai guna ataupun juga mempunyai nilai ekonomis. Misalnya stik es krim, sedotan, kertas bekas untuk barangbarang yang bernilai guna.

\section{Club pramuka}

Club pramuka menjadi salah satu program wajib di SD Semai. Kegiatan kepanduan ini bertujuan melatih kemandirian siswa. Selain itu kegiatan pramuka inimerupakan program wajib yang ada di kuirikulum 2013. Kegiatan ini berlangsung secara rutin seminggu sekali dan diampu oleh pembina pramuka yang disiapkan secara khusus oleh SD Semai.

\section{Club bahasa}

Club bahasa ini merupakan sebuah club yang bertujuan mengembangkan potensi kebahasaan anak selain bahasa Inggris yakni bahasa Arab. Bahasa Arab menjadi salah satu bahasa penting bagi siswa karena mayoritas siswa SD Semai beragama Islam sehinggapenting bagi siswa karena bahasa arab merupakan bahasa kitab suci al-Qur'an yang penjadi pedoman hidup bagi umat muslim.

\section{Club sepak bola}

Club sepak bola merupakan wadah untuk mengembangkanbakat siswa dalam bidang olah raga. Kegiatan ini dilakukan seminggu sekali dengan mendatangkan pekatih khusus.

\section{Club logmath}

Club longmath adalah sebuah program yang bertujuan melakukan pengembangan potensi siswa dalam bidang matematika dan sains. Selain itu, kegiatan ini juga memiliki tujuan mempersiapkan siswa dalam kompetisi olimpiade matematika dan sains.Sebagaimana yang rutin diikuti oleh SD Semai.

\section{Club karate}

Club karate merupakan sebuah kegiatan pengembangan bakat siswa bidang olah raga beladiri. Kegiatan ini dilakukan seminggu sekali. Kegiatan ini telah menampakkan hasilnya dengan menjuarai even kejuaraan karate pelajar. 


\section{Club qiroah}

Club Qiroah merupakan program kegiatan yang bertujuan untuk mengembangkan potensi siswa SD semai dalam bidang seni baca al-Qur'an. Kegiatan ini juga dilaksanakan seminggu sekali.

\section{Club ukir}

Club ukir merupakan kegiatan yang identic dengan potensi lokal Jepara yang terkenal dengan seni ukir dan meubelnya.Sehingga penting bagi SD Semai untuk melestarikan hal tersebut melalui club ukir agar seni ukir tetap eksis dan tidak punah ditelan zaman.

\section{Club tari}

Club tari ini memberikan wadah bagi siswa untuk berekspresi dalam bidang seni gerak tari khususnya tari tradisionl Indonesia.

\section{Club fotografi}

Club fotografi ini bertujuan untuk memberi bekal siswa terkait dengan kemampuan bakat dan dasar-dasar seni fotografi.

\section{Club batik}

Batik club merupakan salah satu kegiatan yang bertujuan untuk mengenalkan warisan luhur nenek morang bangsa Indonesia berupa batik. Batik yang dikenalkan di SD semai antara lain batik tulis dan celup.

Selain sejumlah kegiatan club tersebut masih ada juga kegiatan lainnya seperti club cooking, manasik haji, club dolanan tradisional, family day, bakti sosial dan sebagainya. ${ }^{22}$

\section{Profil Homeschooling Primagama Semarang}

${ }^{22}$ Tim Penyusun, Profil Sekolah Dasar Semai Jepara, (Jepara: Sekolah Dasar Semai, 2018).
Homeschooling Primagama merupakan suatu lembaga pendidikan yang memiliki program pembelajaran setara dengan Sekolah Dasar (SD), Sekolah Menengah Pertama (SMP), dan Sekolah Menengah Atas (SMA). Homeschooling Primagama sering dikenal dengan HSPG memiliki beberapa kantor cabang di Indonesia. Baik di Jakarta, Jawa Barat, Yogyakarta, Jawa Tengah, dan beberapa wilayah lain. Kantor cabang di Jawa Tengah ada dua tempat, yaitu HSPG Semarang dan HSPG Solo Baru .Adapun fokus kajian penulis pada HSPG Semarang, hal itu berdasarkan jarak pelaksanaan penelitian yang lebih dekat dari Jepara.

Homeschooling Primagama Semarang satu lembaga yang terletak di wilayah strategis.Tepatnya di Jalan Abdulrahman Saleh nomor 246, Manyaran Semarang Barat.Homeschooling Primagama memiliki visi "Menjadi lembaga pendamping homeschooling terbaik dan terbesar dengan membentuk peserta didik menjadi pribadi yang mandiri, berkarakter serta mampu mengembangkan potensi akademis dan non akademis secara optimal".

Sedangkan misi Homeschooling Primagama adalah1).Menjadi pelaku homeschooling yang berkualitas, bertaraf nasional dan internasional. 2). Memberikan alternatif sistem pendidikan di Indonesia yang berkualitas nasional maupun internasional. 3). Menyelenggarakan program pendidikan yang mengembangkan potensi akademis dan non akademis berbasis minat dan bakat. 4). Menjadi mitra bagi masyarakat dan pemerintah dalam peningkatan kualitas pendidikan bangsa secara nasional. 5). Menjadi acuan pendidikan alternatif di Indonesia.

Kurikulum yang digunakan oleh Homeschooling Primagama adalah hasil modifikasi kurikulum KTSP 2006 dan Kurikulum 2013 yang disesuaikan pula dengan minat serta bakat peserta didik. Selain itu juga dilengkapi dengan kurikulum international 
Cambridge International Examination (CIE) yang dimodifikasi berdasarkan kebutuhan anak. Dan juga kurikulum program inklusi sesuai kebutuhan peserta didik.

Sistem belajar di Homeschooling Primagama ada empat macam.Sistem pembelajaran ini sebagai alternatif yang dapat diambil oleh siswa sesuai dengan situasi dan kondisi siswa HSPG.

Pertama, sistem belajar individu. Sistem belajar dengan satu pengajar dan satu siswa dalam setiap mata pelajaran. Sistem belajar individu ini dapat dilakukan secara mandiri di rumah bersama orang tua atau dengan guru dari HSPG.

Kegiatan Kedua, sistem belajar komunitas. Sistem belajar komunitas adalah sistem belajar yang diikuti oleh 2-5 siawa dalam satu kelompok belajar. Kegiatan ini dilakukan di HSPG dengan 1 pengajar sesuai bidang studi masing-masing.

Ketiga, sistem belajar distance learning. Sistem belajar distance learning adalah sistem belajar jarak jauh via internet (online) yang menggunakan aplikasi skype, sehingga pengajar HSPG dapat berinteraksi langsung (tatap muka) dengan siswa. Contoh; salah satu siswa HSPG yang berada di Negara Laos yang melakukan distance learning karena alasan jarak yang tidak memungkinkan untuk selalu datang ke HSPG atau sebaliknya guru HSPG untuk datang ke Negara Laos.

Keempat, sistem belajar mandiri. Sistem belajar mandiri ini siswa belajar secara mandiri atau didampingi (orang tua/ pengajar pribadi di luar pengajar HSPG ) dan siswa sepenuhnya mendapatkan hak dan fasilitas dari HSPG.

Homeschooling Primagama juga menyediakan program Private Lesson Exclussive. Program tersebut merupakan les tambahan untuk siswa kelas akhir dalam rangka menghadapi Ujian Akhir Sekolah Berstandar
Nasional (UASBN). Dimana program ini dilaksanakan kurang lebih tiga bulan sebelum jadwal Ujian Akhir Sekolah Berstandar Nasional (UASBN).

Selain materi pelajaran seperti halnya sekolah dasar formal, ada pula beberapa materi tambahan. Materi tambahan atau muatan lokal yang diajarkan di homeschooling Primagama antara lain mata pelajaran Bahasa Jawa dan ketrampilan fungsional. Keterampilan fungsional ini merupakan materi pilihan. Dimana anak dapat memilih materi yang sesuai dengan bakat masing-masing anak. Materi tersebut ada tiga yaitu; Art and Design, Komputer, Cooking, dan Sport. ${ }^{23}$

\section{Homeschooling Primagama juga memiliki} beberapa kegiatan ekstrakurikuler untuk anakanak. Kegiatan ekstra tersebut dibagi menjadi tiga jenis yaitu : (a). Reguler homeschooling Primagama. Reguler homeschooling Primagama merupaka jenis kegiatan ekstra yang diadakan di homeschooling Primagama itu sendiri.Kegiatan dijadwalkan dengan durasi kurang lebih dua jam, mulai pukul 15.00 sampai 17.00 sore.Beberapa ilihan kegiatannya adalah science class, music class, cooking class, dan futsal; (b). Kerjasama Mitra. Pada jenis ini, ada beberapa kegiatan ekstra yang diadakan melalui kerjasama dengan sanggar atau lembaga lain. Antara lainkelas melukis yang kerjasama dengan Sanggar Lukis Pratista, Kelas Tari kerjasama dengan Bailamos Dance School, Kelas sepak bola bekerjasama dengan REAL MADRID Football Club UNY; c). Ekstrakurikuler lain-lain.Anak-anak siswa bomeschooling Primagama dipersilahkan mengikuti beberapa kegiatan non akademis lainnya pada sanggar atau tempat pelatihan lain. ${ }^{24}$ Melalui program ekstra tersebut, anak

${ }^{23}$ Catatan Observasi, Homeschooling Primagama Semarang, Rabu 16 Mei 2018.

${ }^{24}$ Dwi Heni Setyowati, Wawancara Pribadi, Rabu 16 Mei 2018. 
dapat mengasah serta mengembangkan bakat masing-masing secara optimal.

\section{Komparasi Nilai Siswa SD Semai Dengan Homeschooling Primagama}

Pada tahun ajaran 2016/2017, jumlah siswa Sekolah Dasar Semai yang kelas 6 ada 21 siswa, dengan catatan 4 anak berkebutuhan khusus (ABK). Tahun ajaran 2017/2018, jumlah siswa kelas 6 di Sekolah Dasar Semai 15 siswa.13 siswa dengan kondisi psikologis normal, dan 2 siswa termasuk anak berkebutuhan khusus (ABK). ${ }^{25}$ Dalam dua tahun ajaran tersebut, dapat dilihat bahwa di Sekolah Dasar Semai setiap tahun memiliki siswa berkebutuhan khusus yang berhasil mengikuti pembelajaran sampai lulus kelas akhir.

Sedangkan di homeschooling Primagama, pada tahun ajaran 2016/2017 jumlah siswa kelas enam tingkat sekolah dasar ada 4 anak. Dan tahun ajaran 2017/2018 jumlah siswa kelas enam hanya 2 anak. $^{26}$

Pelaksanaan ujian akhir sekolah berstandar nasional Sekolah Dasar Semai dilaksanakan di lokasi sekolah sendiri. Namun bomeschooling Primagama tidak demikian. Ujian sekolah di homeschooling Primagama baik ujian akhir semester kelas rendah maupun ujian kelas akhir mengikuti ujian yang dilaksanakan di homeschooling Primagama cabang Daerah Istimewa Yogyakarta. Hal itu karena jumlah peserta didik di homeschooling Primagama Semarang terlalu minim, sehingga untuk pelaksanaan ujian mengikuti cabang lain terdekat. ${ }^{27}$

Hasil ujian Akhir Sekolah Berstandar Nasional dari tiga mata pelajaran utama Maret 2018.

${ }^{25}$ Tri Mulyani, Wawancara Pribadi, Rabu 14

${ }^{26}$ Dwi Heni Setyowati, Wawancara Pribadi, Rabu 9 Mei 2018.

${ }^{27}$ Dwi Heni Setyowati, Wawancara Pribadi, Rabu 16 Mei 2018. diperoleh data prestasi sebagai berikut :1). Hasil nilai mata pelajaran Bahasa Indonesia Sekolah Dasar Semai lebih unggul dengan ratarata nilai ujian 91,3. Sedangkan rata-rata nilai siswahomeschooling Primagama 82,33; 2). Hasil nilai mata pelajaran Matematika Sekolah Dasar Semai kembali lebih unggul dengan nilai ratarata 82. Dan rata-rata nilai Matematika siswa homeschooling Primagama adalah 80,59; 3). Pada mata pelajaran Ilmu Pengetahuan Alam (IPA), homeschooling Primagama lebih unggul dengan rata-rata nilai 83,31 dibandingkan SD Semai dengan rata-rata nilai 82,5 . Secara umum jika diakumulasi maka diperoleh data bahwa prestasi UASBN SD Semai lebih unggul dengan rata-rata nilai 85,2 sedangkan bomeschooling Primagama dengan rata-rata nilai 82,1 sebagaimana tabel 1 .

Tabel 1. Data Komparasi Nilai Akhir Siswa SD Semai dan Homeschooling Primagama

\begin{tabular}{|c|c|c|c|}
\hline No & Mata Pelajaran & $\begin{array}{c}\text { SD } \\
\text { Semai }\end{array}$ & HSPG \\
\hline 1 & Bahasa Indonesia & 91,3 & 82,33 \\
\hline 2 & Matematika & 82 & 80,59 \\
\hline 3 & IPA & 82,5 & 83,31 \\
\hline & Rata-rata komulatif & 85,2 & 82,1 \\
\hline
\end{tabular}

Hasil angket tentang kepuasan prestasi siswa di Sekolah Dasar Semai menunjukkan 85 persen siswa merasa puas dengan hasil nilai yang dicapai. Dan kurang lebih 15 persen menyatakan kurang puas. Sedangkan homeschooling Primagama menunjukkan 75 persen siswa menyatakan puas dengan hasil belajarnya. Kemudian siswa yang menyatakan kurang puas ada 25 persen. Sebagaimana pada tabel 2.

Tabel 2. Data Komparasi Kepuasan SiswaSD Semai dan Homeschooling Primagama Terhadap Hasil Belajar

\begin{tabular}{|c|c|c|c|}
\hline No & \multirow{2}{*}{$\begin{array}{c}\text { Nama } \\
\text { Lembaga }\end{array}$} & \multicolumn{2}{|c|}{ Rata-rata } \\
\cline { 3 - 4 } & & Puas & $\begin{array}{c}\text { Tidak } \\
\text { Puas }\end{array}$ \\
\hline 1 & SD Semai & $85 \%$ & $15 \%$ \\
\hline 2 & HSPG & $75 \%$ & $25 \%$ \\
\hline
\end{tabular}




\section{Kesimpulan}

Dalam penelitian ini, prestasi belajar yang diteliti hanya nilai dari mata pelajaran utama yaitu Bahasa Indonesia, Matematika, dan Ilmu Pengetahuan Alam. Hasil penelitian menunjukkan nilai Bahasa Indonesia dengan rata-rata 91,3 dan Matematika 82dari siswa Sekolah Dasar Semai lebih unggul dibandingkannilai siswa bomeschooling Primagama Semarang.

Akan tetapi pada mata pelajaran Ilmu Pengetahuan Alam, nilai siswa Homeschooling Primagama Semarang lebih unggul dengan nilai rata-rata 83,31. Secara umum jika dilakukan penilaian rata-rata prestasi belajar mata pelajaran utama diperoleh kesimpulan Sekolah Dasar Semai Jepara lebih unggul dibandingkan Homeschooling Primagama Semarang.

Dari aspek kepuasan terhadap hasil belajar diperoleh data SD Semai Jepara lebih unggul dengan prosentase 85 persen puas dibandingkan homeschooling Primagama Semarang yang nilai kepuasan siswa hanya 75 persen.

Hasil Penelitian ini perlu dilakukan penelitian lanjut tentang hubungan atau korelasi antara kepuasan pelayanan belajar dengan hasil prestasi belajar siswa di Sekolah Dasar Semai Jepara lebih unggul dibandingkan Homeschooling Primagama Semarang.

\section{Daftar Pustaka}

\section{Buku Teks}

Asmani, Jamal Ma'mur, Buku Pintar Home Schooling, (Jogjakarta: FlashBooks, 2012)

Direktorat Pendidikan Kesetaraan, Komunitas Sekolab Rumah Sebagai Satuan Pendidikan Kesetaraan, (Jakarta: Dirjen Pendidikan Luar Sekolah, 2006).

Direktorat PSLB, Pedoman Penyelenggaraan Pendidikan Inklusi (Buku Paket), (Jakarta: Direktorat PSLB, 2004).

Griffith, Mary, Sekolah di rumah, Memanfaatkan Selurub Dunia Sebagai Ruang Kelas, The
Unschooling Handbook, (Bandung: Nuansa, 2008)

Kembara, Maulina D.Panduan Lengkap Home Schooling, (Bandung: Progressio, 2007)

Mandhur, Ibnu, t.t., Lisanul 'Arab, (Riyadl: Dar al-Ma'arif, 1990)

Marsha Ransom, The Complete Idiot's Guide to Homeschooling, (USA: Alpha Publishing, 2001).

Maunah, Perbandingan Pendidikan Islam, (Yogyakarta: Teras,2011)

Moreau, Kathi, Specific Differences In The Educational Outcomes Of Those Students Who Are Home Schooled VS. Students In A Traditional School Setting, (Northern: Michigan University, 2012)

Mulyadi, Seto, Homeschooling Keluarga Kak-Seto: Mudah, Murah, Meriah, dan Direstui Pemerintah, (Bandung: Kaifa PT Mizan Pustaka, 2007)

Mulyasa, E., Kurikulum Berbasis Kompetensi, (Bandung: Remaja Rosdakarya, 2010)

Sugiyono, Metode Penelitian Pendidikan : Pendekatan Kuantitatif, Kualitatif, dan R \& D, (Bandung: Alfabeta, 2010)

Tim Penyusun, Profil Sekolah Dasar Semai Jepara, (Jepara: Sekolah Dasar Semai, 2018)

UU RI No. 20 Tahun 2003 tentang Sisdiknas, 2014, Bandung: Citra Umbara.

\section{Jurnal Ilmiah}

Darmadji, 2013, Tafsir al-Qur'an Tentang Teori Pendidikan Islam: Perspektif Pendidikan Islam di Indonesia, Hermeneutik, Jurnal Tafsir Hadits, volume 9, No.1, JanuariJuni, 223-244.

Pratiwi, Jamilah Candra, "Sekolab Inklusi Untuke Anak Berkebutuban Khusus: Tanggapan Terbadap Tantangan Kedepannya", Prosiding Seminar Nasional Pendidikan; Meretas Sukses Publikasi Ilmiah Bidang Pendidikan Jurnal Bereputasi, Universitas Sebelas Maret Surakarta, 2015 
Siagian, Roida Eva Flora, dan Maya Nurfitriyanti, Minat Belajar dan Karakter Anake Dalam Model Pendidikan Homeschooling di JABODETABEK, Jurnal Pendidikan Karakter, Tahun IV, Nomor 3, Oktober, 2014

Suharni, "Pemahaman Guru Dalam Layanan Bimbingan Pada Sekolah Penyelenggara Pendidikan Inklusi", Jurnal Care Edisi Khusus Temu Ilmiah, Volume 03, Nomor 3, Maret, 2016

Tri Yuni Hendrowati, Persepsi Orang Tua Terbadap Pendidikan Inklusif Sekolah Dasar Di Provinsi Lampung, Jurnal Fokus Konseling, Volume 3, Nomor 1, Januari, 2017

Vania Widyadana Zahida dan Winarsih Dewi, Homeschooling Tunggal Sebagai Model Pendidikan Pilihan Bagi Anak (Studi Analisis Penerapan Konsep Homeschooling Pada Princess), Prosiding Seminar Nasional: Homeschooling Versus Sekolah Formal Dialog Tentang Mutu Pendidikan Yang Bermartabat, Oktober, 2016

Wijayarto, Budi, dan Haryanto, Perbandingan Kompetensi Sosial Siswa Komunitas Homeschooling dengan siswa regular SD Mubammadiyah 1 Surakarta,Jurnal Prima Edukasia, Volume 3 - Nomor 1, 2015

\section{Wawancara dan Observasi}

Catatan Observasi, Homeschooling Primagama Semarang, Rabu 16 Mei 2018.

Dwi Heni Setyowati, Wawancara Pribadi, Rabu 16 Mei 2018. 